\title{
From amateurism to professionalism: sport's transformations by the Brazilian Olympic Athletes' lenses
}

\author{
Katia Rubio \\ Escola de Educação Física e Esporte, Universidade de São Paulo, São Paulo, Brasil
}

Email address:

katrubio@usp.br

\section{To cite this article:}

Katia Rubio. From Amateurism to Professionalism: Sport's Transformations by the Brazilian Olympic Athletes' Lenses. Humanities and Social Sciences. Vol. 1, No. 3, 2013, pp. 85-91. doi: 10.11648/j.hss.20130103.12

\begin{abstract}
Among the various marks that Olympic sports went through along the last century, the transformation of amateurism into professionalism was one of them. Seen, in the beginning, as one of the main Olympic movement's pillars, amateurism was overcome by the contemporary sport's dynamics. It became professional, changing not just the sport's institutions but also the athletes' careers, athletes who are the sporting spectacle's protagonists and also the Olympic Games' reason to be. The current work aims to present how Brazilian Olympic Athletes' career professionalization process happened, as well as how it took place in sport's by the end of last century. Thus, life histories narratives were used as methodology. It is observed, in such narratives, that throughout amateurism, searching for a new career was a normal condition to all athletes. Yet, professionalization did not happen as a national sport's policy, what meant the development of some modalities, but not the development of sports as a whole.
\end{abstract}

Keywords: Professionalism, Amateurism, Life Histories, Olympic Athletes

\section{Introduction}

Sports were originally conceived as a typically aristocratic practice, seen as a leisure activity on the social education environment among non-working classes' children. Such phenomenon passed through many changes as sport started to be held by other social classes, promoting its mass practice and popularization.

Considering that sport was organised, ruled and institutionalised by aristocracy, it's not to wonder that amateurism built itself as one of the fundamental pillars over which laid the Olympic Movement. Once concerned about losing control over sport's practices, which was created to distinguish social classes, its idealisers launched themselves in defence of amateur activities as an ideology. The allowance to Olympic Sports practicing during the Olympic Movement's phase was given to those who did not need to have a regular paid activity to survive, distinguishing, thus, workers from aristocrats.

Created in England in the XIX century, sport was stratified, classifying their practitioners in different ways. We would have, then, sports practiced by professionals, as Box and jogging; school sports, practiced in universities and public schools and amateur sports practiced, basically, by the aristocracy - which dominated the sports institutions direction. That was the basis to the Olympic Movement's creation[1] [2] [3].

It is worth pointing out that sport was performed in public schools attended, at that time, by the elite, it was a social control agent to the youth in such schools. Seen as one of the main and fundamental curricular components in these schools, sport was intimately associated to religion, dominating their practitioners as a 'Muscular Christianity'. Such students supposedly, presented positive skills for both sports and religion. Many of these schools' ex-students became British Empire's representatives throughout the world, further on, disseminating the ethical and moral values learned both in classrooms and with sport. Amateurism's concept was an inherent and fundamental condition to such sport's model Toohey \&Veal[4]. According to the authors, amateurism was a XIX century's construction which aimed to serve the nobility ideals proclaimed by the Victorian Era. The primer and original proposal to amateurism in sport was not just to distinguish, but mainly, to separate the so called 'gentlemen amateur' from all categories' workers... a person who competes for money is not just inferior, but is, before anything else, a person with a dubious personality.

The growing participation of middle and working classes 
in sports activities and in leisure activities in general, was the fundament to such division and classification, once sport was firstly considered an aristocracy's privilege.

Understanding this dynamics is fundamental in order to comprehend the strong Olympic Movement trustees' cling to defend amateurism through more than half of the $\mathrm{XX}$ century. Firstly invented, and turned into tradition afterwards, this concept had changed Olympic Sport throughout more than 80 years. Hobsbawm \& Ranger[5] points out sport's importance to the working classes once it widened social visibility and questioned Class Society. However, the amateurism concept was a way to impel the projection reached by the skilled ones, classifying them as workers, or yet, as sport's workers, what was a distinct condition from those who nobly dedicate themselves to material prises' uninterested practices, despite of good performances.

No amateur could distinct himself/herself in a genuine way regarding sport, unless they could dedicate more time available to them than workers actually had, except if they (workers)were paid to do so. Sports that became more viable to middle classes, such as tennis, rugby and football [...] or the not yet developed winter sports, all of them doggedly rejected professionalism.

Dunning[6] highlights that contemporary society's competitiveness leads to inevitable amateur activity's abandonment, activity that in its core would be the one performed for love, rather than specialised actions able to be developed inside a professional structure that heads to maximum expertise, and such scenario would not happen just in sport.

Amateurism was, in the past, as much a taboo as it was the use of dope substances, it (amateurism) was considered a human virtue and a sinequa non condition to any Olympic athlete. But, more than an ethical value, such imposition was a personal and social qualifier to athletes who willed to follow a sporting career[7].

Even after a century went by, the theme remains up to date, regarding Olympic Studies. Gruneau[2] and Maguire, Barnard, Golding[8] propose a revisit to amateurism' theme as a sociological issue, understanding it, in the Western World, as an ethos or a Social Philosophy, an organizational and cultural practice field and also a wide social movement. He concludes that the amateurism' concept, as it was developed in the early days of 'Olympism', became unsustainable, not just to the Olympic Movement, but also to Western's sport in general terms.

Through his memoir published in 1997, Coubertin finally clarifies his position about the theme. He makes it clear that amateurism's matter was not central to itself but, facing the acquired importance it had to the British community and the political weight such group had inside the International Olympic Committee, it was necessary to stand against the 'danger' that professionalism could represent to the Olympic Games.

Some authors even got to the point of stating that amateurism's matter could compromise Olympic
Movement's own reason to be, in case its basis were not reviewed. It regards to Donnely[9] who considers amateurism fundamental to Olympics, although its development happened inside a quite specific context. According to the author, 'Olympism' is an attitude under extinction in the Olympic world, once more than solidarity and mutual respect, the main referential to perform high competitiveness' sport is the capability to generate financial reward to all directly and indirectly involved ones.

As a consequence of this process, amateurism was slowly replaced and forgotten as being one of 'Olympism's' founding and fundamental elements in the end of the 1970's. From that time on, and in a much more vigorous way, a movement that transformed athletes in company's employees emerged, they borrow their names to teams and athletic groups, thus freeing themselves from sport's professional condition. Such effort was definitely and successfully replaced by contracts with sponsors and companies interested on investing in sport since the 1980's.

Professionalization ended up etching a big change on sport's organizations either from an institutional view point as from competitive activities themselves. More than an evidence of out of average skills' exhibition, sport became a coveted professional career, meaning social mobility for those who were able to overcome competitive career barriers and an option of life for talented youngsters. Athletic competition gained visibility and complexity when became a sporting spectacle and a culture industry's product. Thus, economic expectances linked to policy provisions and government intervention produced and reinforced one of the most robust institutions on the planet.

According to Bourdieu[10] some constitutive keys to sport device's drafted in the XIX century, did not completely change until half of the last century. One of the most significant changes was related to the State's growing presence. It happened because society's 'sportivization' constitutes an important part of distinct agencies' intervention and development that, throughout their acting, defined and created themselves. Besides, Amateurism' Philosophy, which ruled 'Olympism' practically until 1984's Olympic Games, in Los Angeles, was careful on always presenting sport's practices as something independent from the government, presenting them as an individual initiative and also a voluntary association.

As an Olympic Ideal, amateurism constitutes an imperative circumstance of equality among athletes. Although since early times it hadn't have practical effectiveness, Marivoet[11] states that the principles it subsists to are submitted to the competitive framework's differentiation, according to athletes' specificities and skills, in order to guarantee a more equalitarian position, as well as a stronger balance on competitive dimensions.

The sporting participation model developed from the Modern Era's Olympic Games in 1896 foresaw athletes as a being away out of the productive practices and also dedicated to training and improving their sport's performance. 


\section{Methodology}

History of Lives telling was used as methodology for the current research, as in Bosi[12, 13] and Rubio[7], data were collected from 8 Brazilian Olympic athletes' narratives, 7 of them medallists. Narratives had been taken as the dimension adopted by the Cultural Studies Hall[14, 15], they considered the privileged position in the construction and circulation of meanings, as in Guareschi, Medeiros and Bruschi[16] and Silva[17].

Narratives were collected during individual live interviews recorded on audio-visual media, and afterwards transcribed into written files.

Athletes from all over the country and from different sport's modalities were selected, creating approximately eight hundred athletes' database. Out of those eight hundred, eight were selected depending on the importance they gave in their narratives to issues related to the fact being an athlete during times of amateurism and professionalism. Within this framework, there were presented athletes who took place in Olympics since Helsinki, 1952, up to Athens, 2004 among several sport's modalities (Athletics, Basketball, Sailing, Swimming and Volleyball). It was also decided to show these narratives throughout the current article's text, instead of separating specific 'result' parts, once we believe that they illustrate the literature review and the theoretical references on these specific fields.

\section{Being an Amateur Athlete}

Amateurism in Brazil follows the same model globally developed. It can be observed throughout the first half of the XX century that sport when practiced in an amateur way created a social representation of the athlete and it would vary from an eccentric individual, if he/she belonged to aristocracy, to a tramp, if his/her origin was related to popular classes. An alternative way for both models was the military, it used to have sport's practices as mandatory, and, as a result, it took many athletes to the Olympic Games, and even to medal winning, as it happened in Guilherme Paraense's case, in 1920 and João do Pulo, in 1976 and $1980[18]$.

It can be seen, in the period that goes from the beginning of the Olympic Games in 1896 up to Los Angeles, 1984 that Olympic athletes had the amateur status as part of their life's project Rubio[19]. It implied an exclusive dedication to sport's practices, without financial rewarding expectancies, being aware of the need to search for a professional activity in the end of their career as athletes. Such need for searching a profession and a life project to be implemented after their athletic careers led many of them closer to academic studies and to a profession that could or not be linked to sport. Taken as a dream by athletes and their families, time dedicated to training and competitions represented a grant and the end of it was often reported after coming back from an Olympic edition. Such condition can be observed in the career of many Olympic medallist athletes, for generations until 1984.

An example is Manoel dos Santos, 100 meters swimmer, and bronze medallist in the 1960's Rome Olympic Games.

Manoel dos Santos was one of the main swimming sprinters from his time. Besides being little popular in Brazil, he was respected by his opponents abroad and expected in international competitions. He trained in a time when there were no heated pools in São Paulo. Manoel, just for a few times, had the opportunity to face his foreign opponents. Considered as one of the fastest swimmers from his generation he was seen as a possible gold medallist in a swimming competition dominated by Americans and Australians, and at that time, by Japanese.

One year after winning the Olympic medal Manoel dedicated himself to break the word record, what actually happened at Guanabara Club, in Rio de Janeiro.

'Guanabara's pool was a salty water one. There I had the opportunity to break the world record... at the time was quite celebrated because Brazil had no expression in sport'.

Once he broke the record in the age of 21, Manoel considered his swimming goal accomplished. Concerned about future, which involved a profession and marriage, he made the option to turn to his family's business, where he stayed until 1984, when he decided to return to his initial track, swimming, and opened a gym[18,7].

Obviously, social origins also influence the transition process over athletes' careers. Those whose families had good financial sources to invest in their children' sport's practices if, in one side, gave them conditions to dedicate themselves to their career, in the other, also put an end to their dreams, once families understood the need to develop a long term professional activity. Maybe, it had distinguished the three medallists bellow: Adhemar Ferreira da Silva, two times triple jump Olympic champion (Helsinq, 1952 and Melbourne, 1956), Carmo de Souza, known as 'Rosa Branca', two times basketball world champion and two bronze Olympic medals (Rome, 1960 and Tokyo, 1964) as well as Alex Welter and Lars Björkström, gold medallists (Moscow, 1980).

Adhemar was a singleton of a railroad employee father and a laundress mother. He started in Athletics when chosen by a coach, with clinical eyes, who saw in his body type the condition to be an athlete. At that time, he conciliated work, studies and training. Working took all his time. He studied at night and practiced at lunch time. Besides such exemplary behaviour, the public employee, Adhemar, got no recognition for his deeds.

Adhemar went to 4 Olympic editions and conquered two gold medals. He is known as one of the biggest Olympic athletes in the XX century. The first medal, in 1952, was a milestone to the Olympic Sports, which had just accomplished such deed in 1920, with Guilherme Paraense. In regards to it, 'A Gazeta Esportiva' journal launched a campaign to donate a house to Adhemar, whose family was living in a rented house. Being aware that accepting the donation would represent a professional attitude, Adhemar refused the offer, in order to keep competing. Adiel, 
Adhemar's daughter, told us what that meant to him and his family:

"My grandmother was all happy because the population acceded, there were many subscription, they were already buying the house. Then, with his heart broken, he had to call his parents and say: 'look, I want to go on and the condition is to not accept this house, because, otherwise I become professional. First they will come here and will take away all my medals, my trophies and it's over. I can't'.",

After to refuse the house he participated on two other Olympic editions and won one gold medal more. He also studied and graduated in Arts, Physical Education, Law, Public Relations and got a Journalist's Register. He was Brazil's Cultural Attache in Nigeria for three years.

'Rosa Branca' has a similar background. Born in São Paulo State's interior, since his early ages he worked to help his humble family. He was a shoemaker, a banana seller in free markets and a water carrier. Among all his obligations, school was as important as work. In his school had a strong Physical Education Department and all the material conditions to support many sport's modalities practice. He started with athletics and moved to basketball in which he would become an idol of the country's second sport's modality, at that time. In 1959 and 1963 he was part of the team that won the world title and also a bronze medal in 1960 and 1964 Olympic Games.

In 1967 Harley Globetroters' manager tried to take 'Rosa Branca' to the United the States, however, once he was concerned about losing his amateur status, he refused the invitation.

"At that time it was money that would never end. 40 thousand dollars...I would have to become a professional and would lose all my titles too... Then, I thought well and said: 'I will leave these 40 thousand aside. But these titles... would all stay in Brazil. It wouldn't be fair".

Graduated in Physical Education he dedicated himself to teaching and to activities such as sport's coaching $[18,7]$.

Yachtsmen partners Alex Welter and Lars Björkström case goes in a little different direction. Here they will be called 'partners' once they define their performance as a successful marriage.

Alex was a Brazilian son of a German father and Austrian mother. He studied in a German School in São Paulo, and was taken by his uncle, a man crazy about ships, to start his sailing practices. As all other children at that time, the first sailing notions were learned in a Penguin Class boat, after that, he jumped to a Finn Class one and afterwards to a Tornado, in which he met a Swedish called Lars Björkström.

Lars Björkström was born in Sweden and introduced to sailing practicing by an uncle. He naturalised Brazilian in 1979 and, along with Alex, competed in 1980's Olympic Games when they were helped by the boycott leaded by the North-Americans. They won an unprecedented gold medal to Brazil. After the party, tributes and the first signs of sport's professionalization, Brazilian Olympic Committee's president, Major Sylvio Magalhães Pinto made it worth to tell them:

"Take care or then you lose your medal'. You could not get a penny you could not make any advertisement, nothing of this".

It can be observed, regarding the yachtsmen partners' history, that, despite the fact that passion for sailing was their motivation to search for a life style that would enabled a match of profession and sport, there was a moment when they had to make a chose and opt for their professions because they needed to fulfil their lives demands. Facing the possibility that they could get some kind of help that would characterise being a professional, a message was sent by the Brazilian Olympic Committee to them, trying to leave no doubt about the way to take: professionalization meant losing the medal.

Even if the former COB (Brazilian Olympic Committee) president did not mean to, amateurism times were living their last days. Professionalization was as inevitable as competitions are to sports.

\section{The Athlete's Work}

The Modern Era's Olympic Games passed through the XX century and survived two World Wars, two declared boycotts and a few masked ones, but did not support financial power's strength that overcame the amateur spirit after Los Angeles' Games - 1984 [20] [21] [22].

A new commercial order was established as television entered the Olympic world. The visibility athletes got stimulated commercial companies to have their brands associated to those super-humans capable to uncommon achievements. Facing the risks that signing contracts could represent to the athletes' careers, the possible way would be skip the rules by means of unexpected actions as Mark Spitz did in 1972's Munich Olympic Games, when he went up the podium with a pair of tennis shoes hanged on this neck. It was the way he found to show his sponsor, a sports' gear producer, that could not have his brand advertised because the modality was too specific[23] [24].

Another fact that leaded to a professionalization search not just among athletes, but by the International Olympic committee's structure as a whole, was the Olympic Games giant growth. The need of bigger infra-structure to allow competition events, as well as accommodations to thousands of athletes, tourists and support coaches, linked the Games' production to governments' political goodwill in countries where they would take place. Such dynamics was kept until 1976's Montreal Games. Montreal, Quebec County's capital, represents the biggest part of Canada's French speaking portion and, therefore, smaller population portion of the Canadian Republic. Differences among communities and political rivalries made the Canadian government inform the Game's organisers that not even a penny would be spent on sites built to such aim. Although, local government would receive 34.5 million dollars for television transmissions' rights, it dealt with an approximately 1,7 billion dollars loss, which was turned 
into taxes that Quebec population had to pay until the year $2000[25][26][23]$.

After such experience, the need to search for new strategies for the next Olympic Games - which started to get new shapes because of the boycotts promoted by the United the States and its allies in 1980 and, afterwards by the Soviet Union and the countries on the socialist block in 1984, as well as Juan Antonio Samaranch 1980 election as IOC's president - was certain.

Big companies financing the Games seemed inevitable according to the host cities imposed needs. Los Angeles, 1984, was used as a lab to this new experience. At that time, besides the boycott, North-American government did not take one single penny out of the public saves to help construction sites. In the other hand, sport's marketing showed its reason to be, promoting enough source catchment in order to cover all the expenses and yet generate some earnings to its organisers. Paths to new Olympic directions were opened, and they would have no way back.

In 1998's Seoul Games, athletes and teams tested their ability to make their sponsor's brands shine, but it was the 1992's Barcelona Games that actually marked the beginning of sport's professionalization. Although Basketball had marked this Olympic edition, some other modalities associated to the professional sport's world also were allowed for the first time in Barcelona. It was the case of cyclists who were involved in competitions such as the 'Tour de France', the owner of the greatest money prise in the modality, and also the best tennis players in the world ranking.

The growing difficulty to succeed in sports is a more and more competitive social context, and it has been forcing earlier sport's initiation among many modalities.

According to Ferrando[27], such early recruiting is more evident among team modalities when compared to individual sports, and differently from other periods in which sport's practicing initiation was performed in public locations, today there is also an early institutionalization, once open areas are getting scarcer every day. The way initialization is done today points to a more institutionalised competitive sport's model that has been implemented, setting in strong ways, an individual way towards sporting excellence.

The author remembers that an amateur athlete is defined as a person who never had a coach and who does not even train his/her sport's activities. The non-rewarded sport's practices, emphasised by the European bourgeoisie in the end of the XIX century and begin of the XX, was kept by most of the Contemporary Olympic Movement's directors, almost all of them members of social, economic and political privileged groups. However, high performance's sport turned into such a qualified thing that, in a technical point of view, its most dedicated and detached practitioners, are closer to the working class - a class that was supposed to be kept out of sport - than the bourgeoisie direction.

This is Ferrando's[27] reason to call high performance athletes 'sport's workers', once having their professional practices, generous advertisement contracts, requirement for medium and social security as well as a detachment from de Olympic ideal as a counterweight. Athletes with such a profile, besides presenting various social classes, often come from low and middle social classes, and they point out sport as an obstacle to perform another function, it makes them look for professionalization.

If professionalization represents the possibility of a sport's career just as in any other profession, it is necessary to consider that in other expertise, retirement happens according to working time, following working polices that guarantee further social financial support. Regarding athletes, career transition, which means retiring, happens inside his/her active vital cycle, usually around their 30 's, or before, depending on their modality, without social financial support's guarantee. It shows the need to initiate a whole preparation to face the unknown challenges that no longer depend on their physical abilities. And, differently from the amateurism's period, when such end was clear and waited, so athletes would study and get prepared for a new career, in the professionalism's period, the rule had changed.

Professionalism in Brazil's Olympic sports started in the beginning of the 1980's, through Volleyball, which in 1984 won the first silver medal and in 1992, the first gold one. It has been winning since. 1984's generation gave the first steps towards professionalization, when there was not a national contract model yet. Thus, athletes were hired as employees for specific activities in sponsor's companies, but not as athletes. If on one hand it helped exclusive dedication in order to form a winner's generation, in the other, it jeopardised the construction of a professional identity in such athletes.

Amauri Ribeiro was a medallist in 1984 and in 1992 . He played volleyball at school, the place where a local team's coach saw him playing and invited him to play in a tournament organised by the volleyball federation. After that tournament, another team, yet an amateur one, but well known in national championships, invited him in. He tells that the beginning of his career in the 1980's had no sponsor.

"I won a 'Colégio Objetivo'scholarship to play the games. It was there that I ended up doing my first contract. Volleyball was purely amateur what we had in benefit was this, support".

It was after the first professional teams were launched, Atlântica Boa Vista, in Rio de Janeiro, and Pirelli, in São Paulo in 1981, that he started to earn a salary to play, however he was hired as a company's employee.

The mentioned generation opened paths for the one that came right after and that further on was called the gold generation. Giovane Gávio is part of it.

He started his history in the age of 12 . He was quite influenced by the generation that would win the silver medal in 1984's Los Angeles Olympic Games. By the age of 16 , he was invited to play in a juvenile volleyball team 
in São Paulo, sponsored by Banespa Bank. The team was one of Brazilian volleyball's strongest teams in the end of the 1980 's and in the 1990's. In 1990 Giovane went to play in Italy and stayed there for four years. He was the best paid player of his time, but his performance requirements were just as high as his salary.

'There I had to deal with responsibility. The match point ball would go to the foreigner, so it was for me. It was me who earned more than the whole team, so I had to decide.'

He was one of the team holders who won the gold medal in Barcelona's Games and was elected the best player in the world. At that time, the pressure for good results actually started. Defeats could mean losing not just the titles, but, mainly, the sponsors.

'...94, already we got into a period where there was much pressure much intense and external requirements. There were a lot of sponsors, so I thought that I had to play always well because otherwise sponsors would get sad or would not keep sponsoring me. So, in a certain way it was an unnecessary weight that I hold in that period. At the same time the national team experienced all these new sensations. Kept on asking why one earns more money that the other? Many new things at the same time and we did know how to deal with it.

After the 1996's defeat, Giovani made the option for playing beach volleyball and did it up to the year 2000, when he was invited to join the Court Brazilian Team and play Sydney's Olympic Games, getting the $6^{\text {th }}$ place. In 2001 coach Bernardinho called him in and gave him a new chance in the Brazilian Team. In 2003 he was considered the best striker in the world and in 2004 he became an Olympic winner again. Nowadays, Giovani is volleyball team's coach.

Giovani's career is an example of success in many ways. Once he was a special athlete in many teams where he played, such as the Brazilian Team, his image was strongly used as a mark of success and seriousness. It brought him many sponsors throughout his active time and also credibility, regarding the professional profile he had developed.

Another athlete seen as an example for the professionalism's period is Joilto Santos Brasil, Athletics. In 1981 he was a highlight in the Brazilian Students Games and went to the Students World Tournament in France, in 1982. In 1987, he went training in another town, when his time marks considerably improved. He started to hang around the world athletics circuit and got to Barcelona Olympic Games aiming to reach the semi-finals, however he's got the flu in the Olympic Village and it took him away from his goal. After that he started to study. In 1996 he scored to go to 1996's Atlanta Games, but in the lest selection and unexpected event made him loose the chance to get to the Olympic Games, reinforcing his wish to stop practicing athletics, although sport was his profession and where he earned his livelihood.

Although he had lived the professionalism's phase, Joilto is an example of athlete who did not have the professional conditions to stand among the bests. He dedicated himself to competitive athletics for 18 years. He was the Brazilian Champion many times and went through many difficulties until he could establish a new profession many years after the end of his career. In 2008 he was approved in a public contest and nowadays he is a 'Correio's' (Brazilian mail company) Engineer, in Brasilia.

\section{Final Considerations}

The stories told suggest that the transition from amateurism to professionalism has not happened in different sports in Brazil. This does not allow the country to achieve the competitive level necessary to Olympic sport of the great world powers.

If during amateurism' phase sacrifice was accepted as a necessary condition to reach success, getting to the Olympic Games or winning medal was a reward for such dedication. By professionalism's period, bad life conditions represented the frustration got from bad results and the time wasted in a project expected to fail. Amateurism's world turned around a moral appeal given to athletes known as timé, a Greek term that means 'honor', just as areté, that represents decency, a value that was not learned by conduct rules transmission, but by life practices from valorous people [28].

Olympic Sports in Brazil highlights the success of a few people who, once determined to overcome their physical and social limitations, wrote their names in sport's history, in the country and abroad. Besides gratifying and delightful sport's career was an activity marked by an expiring date which, although delightful, was not a guarantee for future and stability, not even to medallists and Olympic winners.

In such sense, the search for an athlete happened, basically, through the possible results inside the practice of his/her modality as: marks, time and a positive result when facing an opponent. The athlete's body, in such perspective, and results itself, were sings of athletes' career longevity and impossibility to keep on reaching desirable marks which were the indicators of a possible production limit. Thus, career transition, more than a dramatic event, was part of a natural process that, among other things, involved an academic career continuity that was initiated along with the athletic career. We do not wish to state that the process here was intense and dramatic as it is the end of any compulsory situation, inexorable. But, in any case, we observed productive life's continuity and the search for new deeds and dreams.

Since the beginning of sport's activities and regular competitions, such condition is reinforced by the argument that a seller athlete is the one who wins tournaments and is crowned by medals. The interpretation of such situations points towards these athletes tendency to fight and, consequently, to agonistic. Despite an initial individual disposition for sports' practicing that can lead to professionalization, it is possible to realise, throughout many athletes' paths, the influence of external elements, as 
for example: other athletes life histories' and the media systematic exposition of their careers and victorious situations, placing a direct interference over the seller concept and in the construction of sport's imaginary and repertoire, where the defeated one is rewarded with solace.

Indications as those, shows that an athletes' career is not just the result of an individual willingness and talent or of a reinforcement of a core desire or even of the determination to run for a goal. External issues as: parents, political policies and the former's role, can influence and even determine the transformation of an aspirant into an athlete.

After the trajectory starts other elements are added to it, and they place the particular athlete among those who accomplished fame and status, and they become the current reference in their modality, or to those who search for prestige through actions and gestures, a condition that in a certain sense favours longevity and permanence.

\section{References}

[1] Gorman, D. Amateurism, Imperialism, Internationalism and the First British Empire Games, The International Journal of the History of Sport, 2010. 27 (4): p. 611-634.

[2] Gruneau, R. 'Amateurism' as a Sociological Problem: Some Reflections Inspired by Eric Dunning, Sport in Society: Cultures, Commerce, Media, Politics, 2006. 9 (4): p. 559-582.

[3] Holt, R. Amateurism and its interpretation: The social origins of British sport. Innovation, The European Journal of Social Science Research, 1992. 5 (4): p. 19-31.

[4] Toohey, K. \& Veal, A. J. The Olympic Games: a social Science perspective. 2007. Oxfordshire/Cambridge: CABI, p.: $15-16$.

[5] Hobsbawn, E. \& Ranger, T. A invenção das tradições. 1997. Rio de Janeiro: Paz e terra, p. 256.

[6] Dunning, E. A busca da excitação. 1992. Lisboa: Difel.

[7] Rubio, K. Medalhistas olímpicos brasileiros: histórias, memórias e imaginário. 2007. São Paulo: Casa do Psicólogo.

[8] Maguire, J., Barnard, S., Butler, K., Golding, P. 'Celebrate humanity' or 'consumers?': A critical evaluation of a brand in motion. Social Identities: Journal for the Study of Race, Nation and Culture, 2008. 14 (1): p. 63-76.

[9] Donnely, P. The local and global: globalization in the sociology of sport, Sports \& Social Issues, 1996. 20 (3): p. 239-257, August.

[10] Bourdieu, P. Deporte y classes sociales, in Materiales de Sociologia del Deporte. 1993. Madrid: Las Ediciones de La Piqueta.

[11] Mariovet, S. Aspectos sociológicos do desporto. 1998 Lisboa: Livros Horizonte.
[12] Bosi, E. O tempo vivo da memória. 2003. São Paulo: Ateliê editorial.

[13] Bosi, E. Memória e Sociedade. 1994. São Paulo: Cia das Letras.

[14] Hall, S. Da diáspora. Identidades e mediações culturais. 2003 Belo Horizonte/Brasília: Editora UFMG/ Representação da UNESCO no Brasil.

[15] Hall, S. Quem precisa de identidade? In. Identidade e diferença. A perspectiva dos Estudos Culturais. 2000. Petrópolis: Vozes.

[16] Guareschi, N. M. F., Medeiros, P. F.; Bruschi, M. E. Psicologia Social e Estudos Culturais: rompendo fronteiras na produção do conhecimento. In: N. M. F. Guareschi \& M. E.Bruschi (eds) Psicologia Social nos Estudos Culturais. 2003. Petrópolis: Vozes.

[17] Silva, T. T. A produção social da identidade e a diferença. In: T. T. Silva (ed.) Identidade e diferença: a perspectiva dos Estudos Culturais. 2000. Petrópolis: Vozes.

[18] Rubio, K. Heróis olímpicos brasileiros. 2004. São Paulo: Zouk.

[19] Rubio, K. Jogos Olímpicos da Era Moderna: uma proposta de periodização. Revista Brasileira de Educação Física e Esporte, 2010. 24 (1): p. $55-68$.

[20] Grix, J. 'The Politics of Sports Mega-events', Political Insight, 2012. 3 (1): p. 4-7, April.

[21] Kellett, P., Hede, A-M.,Chalip, L. Social policy for sport events: Leveraging (relationships with) teams from other nations for community benefit, European Sport Management Quarterly, 2008. 8: p. 101-121.

[22] Riordan, J. Amateurism, Sport and the Left: Amateurism for All Versus Amateur Elitism, Sport in History, 2006. 26 (3): p. 468-483.

[23] Papanikolaou, P. The Spirit of the Olympics vs. Commercial Success: A Critical Examination of the Strategic Position of the Olympic Movement, International Journal of Humanities and Social Science, 2012. 2 (23): p. 1-5, December.

[24] Preuss, H. Economics of Staging the Olympics: A Comparison of the Games 1972-2008. 2004. Northampton: Edward Elgar Publishing.

[25] Andranovich, G.; Burbank, M. J.; Heying, C. H. Olympic Cities: Lessons Learned from Mega-Event Politics, Journal of Urban Affairs, 2001. 23 (2): p. 113-131, Summer.

[26] López, A. A. La aventura olímpica, 1992. Madrid: Campamones.

[27] Ferrando, M. G. Los deportistas olímpicos españoles: un perfil sociológico, 1996. Madrid: Consejo Superior de Deportes.

[28] Rubio, K., Carvalho, A. L. Areté, fair play e movimento olímpico contemporâneo. Revista Portuguesa de Ciências do Desporto, 2005. 5 (3): p. 350 - 357. 